\title{
INTRODUCTION
}

\section{Disease effects on lobster fisheries, ecology, and culture: overview of DAO Special 6}

\author{
Donald C. Behringer ${ }^{1,2, *}$, Mark J. Butler IV ${ }^{3}$, Grant D. Stentiford ${ }^{4}$ \\ ${ }^{1}$ Program in Fisheries and Aquatic Sciences, School of Forest Resources and Conservation, University of Florida, Gainesville, \\ Florida 32653, USA \\ ${ }^{2}$ Emerging Pathogens Institute, University of Florida, Gainesville, Florida 32610, USA \\ ${ }^{3}$ Department of Biological Sciences, Old Dominion University, Norfolk, Virginia 23529, USA \\ ${ }^{4}$ European Union Reference Laboratory for Crustacean Diseases, Centre for Environment, Fisheries and Aquaculture \\ Science (Cefas), Weymouth Laboratory, Weymouth, Dorset DT4 8UB, UK
}

\begin{abstract}
Lobsters are prized by commercial and recreational fishermen worldwide, and their populations are therefore buffeted by fishery practices. But lobsters also remain integral members of their benthic communities where predator-prey relationships, competitive interactions, and host-pathogen dynamics push and pull at their population dynamics. Although lobsters have few reported pathogens and parasites relative to other decapod crustaceans, the rise of diseases with consequences for lobster fisheries and aquaculture has spotlighted the importance of disease for lobster biology, population dynamics and ecology. Researchers, managers, and fishers thus increasingly recognize the need to understand lobster pathogens and parasites so they can be managed proactively and their impacts minimized where possible. At the 2011 International Conference and Workshop on Lobster Biology and Management a special session on lobster diseases was convened and this special issue of Diseases of Aquatic Organisms highlights those proceedings with a suite of articles focused on diseases discussed during that session.
\end{abstract}

KEY WORDS: Panulirus argus virus $1 \cdot \mathrm{PaV} 1 \cdot$ Hematodinium · Gaffkemia $\cdot$ Aerococcus viridians · Shell disease $\cdot$ ESD $\cdot$ Aquimarina homaria $\cdot$ Intersex $\cdot$ ICWL

Resale or republication not permitted without written consent of the publisher

Lobsters support commercial fisheries worldwide with landings of nearly $280000 \mathrm{t}$ and efforts to grow and market lobsters or enhance natural lobster populations using aquaculture are growing (FAO 2012). Beyond their value as a seafood commodity, lobsters of the spiny, clawed, and slipper varieties are also some of the most abundant large benthic invertebrates in their ecosystems and often of significant ecological importance as predators and prey (Butler et al. 2006, Lavalli \& Spanier 2007). Yet, in recent decades disturbing reports have surfaced describing diseased lobster populations. Disease is increasingly recognized as a prominent force driving the popula- tion dynamics, fisheries, and ecology of many marine organisms and the apparent rise in lobster disease has brought focus to them, culminating recently in a special session on disease at the 2011 International Conference and Workshop on Lobster Biology and Management in Bergen, Norway. This special issue of Diseases of Aquatic Organisms (DAO) draws from that session with recent studies on several of the most consequential lobster diseases.

The literature indicates that lobsters do not face as large a number of pathogens and parasites as do other decapod crustaceans (e.g. shrimps and crabs). However, several diseases pose significant threats to 
lobster populations in the wild or in post-capture holding facilities (see Shields 2011, Stentiford \& Neil 2011, and Cawthorn 2011 for reviews). Parasitic dinoflagellates of the genus Hematodinium, the viral pathogen Panulirus argus Virus 1 (PaV1), the pathogenic bacteria Aerococcus viridians var. homari (gaffkaemia), and the syndromic epizootic shell disease (ESD) all occur in wild animals and have impacted holding and processing facilities to varying degrees. Other decapod pathogens have only been experimentally transmitted to lobsters, such as white spot syndrome virus (WSSV), but may have the potential to impact wild stocks. The studies in this DAO Special cover these pathogens in the context of the pressing issues that they create for lobster fisheries, patho-biology, and ecology.

Hematodinium sp. is a dinoflagellate parasite with broad host specificity, infecting more than 35 crustacean host species (Small 2012). It has had devastating impacts on crab populations worldwide (Morado 2011) and is a major source of mortality for juvenile Norway lobster Nephrops norvegicus around the UK. Prevalence of Hematodinium in N. norvegicus and the associated mortality of lobster around the UK have long been assumed to be seasonal, but Beevers et al. (2012, this DAO Special) challenge that notion with compelling new evidence to the contrary. They used a suite of assays over a nearly 2-yr period to show that a combination of assay insensitivity and variable parasite dynamics led to this erroneous conclusion; instead, it appears to be the intensity of infection, rather than prevalence per se, which varies among seasons (Beevers et al. 2012).

Infection with Hematodinium sp. imparts a bitter flavor and cooked appearance to the meat of some crab species yielding them unmarketable (Meyers et al. 1987, Taylor \& Khan 1995). This condition gave rise to the term 'bitter crab disease' (BCD) commonly used to describe infections. Albalat et al. (2012, this DAO Special) used a sensory evaluation panel and biochemical analysis to test the quality and palatability of cooked Nephrops norvegicus patently infected with Hematodinium sp. They found that even after cooking, the meat was of considerably lower quality and flavor than that of non-infected lobsters, but surprisingly, it did not have the characteristic bitter taste described for some crab species (Meyer et al. 1987, Taylor \& Khan 1995).

In contrast to Hematodinium, PaV1 has a very narrow host specificity and is only known to infect the Caribbean spiny lobster Panulirus argus (Butler et al. 2008) but does so throughout the Caribbean-wide range of $P$. argus (e.g. USA, Shields \& Behringer
2004; Mexico, Huchin-Mian et al. 2008; and Cuba, Cruz-Quintana et al. 2011). Infections of PaV1 can cause locally high juvenile mortality of up to $60 \%$ (Behringer et al. 2011); mortality is much lower in adults. Shields \& Behringer (2004) first hypothesized that lobsters infected with PaV1 died due to metabolic wasting, further supported by observations of depressed nutritional condition in infected lobsters (Behringer et al. 2008, Briones-Fourzán et al. 2009). Pascual-Jiménez et al. (2012, this DAO Special) used a more comprehensive suite of 13 variables to investigate how natural PaV1 infections alter the physiology, immune response, and perhaps the immuno-competency of Caribbean spiny lobsters. PaV1-infected lobsters had significantly different profiles in these characteristics suggesting that their immune response was activated in some respects, but potentially suppressed in others (PascualJiménez et al. 2012). They also report the first PaV1 co-infection with PaV1-infected lobsters having a nearly $50 \%$ higher prevalence of gill infestation by an opportunistic ciliate (Epystilis sp. and Zoothamniun sp.) compared to lobsters without a PaV1 infection (Pascual-Jiménez et al. 2012).

PaV1 also has striking effects on the ecology of Panulirus argus including the avoidance of infected lobsters by normally social and healthy conspecifics (Behringer et al. 2006). This behavior has implications for trap-based fisheries that rely on lobsters' sociability to catch them (Behringer et al. 2012), but many fisheries in the Caribbean use non-confining structures termed 'casitas' (1 to $2 \mathrm{~m}^{2}$ ) to attract lobsters and facilitate their harvest. Candia-Zulbarán et al. (2012, this DAO Special) and Briones-Fourzán et al. (2012, this DAO Special) studied the effects of commercial-scale (>18000 casitas) casita use on the prevalence and distribution of PaV1, and the behavior of lobsters in relation to diseased conspecifics in Bahía de la Ascensión on the Mexican Yucatan peninsula. Candia-Zulbarán et al. (2012) used the presence of clinical (i.e. visible) infections to show that PaV1 prevalence varied with season, location, and lobster size, but was unaffected by the presence of casitas. Although visible infections of PaV1 were high in juveniles they were very low in adults, as has been observed in the Florida Keys (Shields \& Behringer 2004) and Cuba (Cruz-Quintana et al. 2011). However, unlike the Florida and Cuban fisheries where lobster catch has declined over the past decade (Ehrhardt et al. 2010), lobster fishery production in Bahía de la Ascensión has increased by 25\% over the same period (Sosa-Cordero et al. 2008). Briones-Fourzán et al. (2012) also found that PaV1 in- 
fection did not alter the sheltering patterns of lobsters that use casitas, in contrast to observations in smaller natural shelters where uninfected lobsters will not share a den with a PaV1-infected lobster (Behringer et al. 2006, Lozano-Álvarez et al. 2008). Even at the highest levels of co-occupation within casitas, prevalence of PaV1 was low. Thus, the large size of casitas may permit sufficient separation of infected and uninfected lobsters to curtail transmission of PaV1 as compared to transmission measured in standard fishing traps (Behringer et al. 2012) and in the laboratory (Butler et al. 2008), or perhaps greater UV radiation limits water-borne transmission of PaV1 in the clear, shallow waters of the Yucatan (Briones-Fourzán et al. 2012).

The American lobster Homarus americanus supports one of the largest fisheries in New England (USA) and Atlantic Canada with > 115000 t landed in 2010 (FAO 2012). Due to the collapse of many finfish fisheries some argue that the New England fishermen have become overly dependent on a single-species fishery, albeit one that for much of the region appears healthy with record harvests. However, in the mid 1990s lobsters with deep shell lesions, sometimes covering most of their carapace, began to appear in traps in southern New England (Castro \& Angell 2000). The condition was termed 'epizootic shell disease' (ESD) (Smolowitz et al. 2005). A potential causative agent has recently been identified, the bacteria Aquimarina homaria (Quinn et al. 2012), although other co-infecting pathogens and conditions (environmental or physiological) confound a simple cause-effect relationship and potentially increase lobster susceptibility to ESD. At present, therefore, ESD is considered as syndromic. By 2011, the epizootic had so decimated lobster stocks in southern New England that the Atlantic States Marine Fisheries Commission deemed the southern New England fishery in collapse and recommended it be closed. Fishery models incorporating shell disease offer convincing evidence that ESD has indeed been a major factor in the decline of the stock (Wahle et al. 2009), underscoring the importance of considering disease in stock assessments and fishery management. ESD prevalence remains high off the coast of southern New England, where it varies temporally and geographically between 10 and $40 \%$ (Castro et al. 2012, this DAO Special). Castro et al. (2012) have reviewed the current state of knowledge on ESD including developments on the potential etiological agent, fishery effects, and environmental correlates and they discuss future research avenues and needs.
The American lobster fishery has had problems with disease in the past, notably gaffkaemia, a fatal disease first reported in 1947 (Snieszko \& Taylor 1947) and caused by the bacteria Aerococcus viridians. Gaffkaemia is often reported from lobster held in impoundments prior to sale, where injuries to lobsters are common and facilitate pathogen transmission. However, several studies also document its presence in wild lobster populations along the northeast Atlantic coast (Stewart et al. 1966, Lavallée et al. 2001). Homarus americanus also has a close relative across the Atlantic in the European lobster $H$. gammarus, and gaffkaemia has been reported from facilities where imported American lobsters were held together with European lobsters. The introduction of novel pathogens to naïve but potentially susceptible populations is a great concern. Therefore, Stebbing et al. (2012, this DAO Special) surveyed wild populations of $H$. gammarus around the coast of England and Wales to determine if gaffkaemia is now endemic in wild stocks of European lobster. They confirmed via genetic analysis that gaffkemia is indeed present at low prevalence $(<1 \%)$ in wild $H$. gammarus in the $\mathrm{UK}$ and that the bacterial strain present in Europe is most likely of USA or Canadian origin.

To potentially curtail a similar introduction of an even more devastating pathogen, Bateman et al. (2012, this DAO Special) investigated the viability of white spot syndrome virus (WSSV) in supermarket commodity shrimp and its potential for spread to Homarus gammarus. WSSV has had catastrophic effects on the penaid shrimp industry (reviewed in Lightner 2011 and Stentiford et al. 2012), and similar to Hematodinium, WSSV has a broad host affinity (Stentiford et al. 2009). The supermarket-derived shrimp sampled by Bateman et al. (2012) did indeed harbor viable viral particles that were transmissible to penaeid shrimp. WSSV was also successfully transmitted to $H$. gammarus fed infected supermarket-derived shrimp, but transmission required exposure to heavily infected shrimp. These are ominous results that highlight the threat of potential disease introductions assisted by greater international trade in crustaceans.

In addition to pathogens, pollutants and contaminants can cause mass mortality of wild crustaceans, as occurred off the coast of Rhode Island (USA) after a fuel oil spill in 1996 (Cobb et al. 1999). Other contaminants can be more insidious in their impact on decapod crustaceans. For example, endocrine-disrupting chemicals may cause abnormalities such as intersex individuals, which develop anatomical characteristics of both sexes (see Stentiford 2012 and ref- 
erences therein, this DAO Special). Intersex was recently observed in Homarus gammarus from the English Channel, UK (Stentiford 2012). Observations such as this can yield insight into the effects that contaminants can have on marine organisms and the potential avenues through which contaminants may facilitate susceptibility to pathogens.

The studies included in this DAO Special demonstrate how profoundly pathogens and parasites can impact lobster host populations, and underscore the need to approach disease research proactively and from a multi-disciplinary perspective. Lobsters are relatively hardy organisms and their populations robust to moderate levels of exploitation and habitat alteration. However, when stressed by sufficient fishery exploitation or environmental degradation, these same populations can episodically succumb to pathogens that overwhelm their immunological and behavioral mechanisms of resistance. Understanding this complex interplay between pathobiology and ecology requires us to continue to broaden our scientific approach to include disciplines such as ecology, oceanographic modeling, and fishery stock assessment.

Acknowledgements. We are grateful for the support of the 2011 International Conference and Workshop on Lobster Biology and Management, especially the chair of the host committee, Dr Gro van der Meeren, who greatly facilitated our organization of the special session on lobster diseases. D.C.B. and M.J.B. also acknowledge support provided by the US National Science Foundation (OCE-0928930) for travel and research on lobster disease. G.D.S. acknowledges the support of the European Commission under contract C5202, and the UK Department for Environment, Food and Rural Affairs (Defra) under contract FB002 for supporting time and research to contribute to this DAO Special. Finally, we appreciate the timely submission and revision of articles by the authors of this DAO Special, and the thoughtful comments by reviewers of these studies.

\section{LITERATURE CITED}

Albalat A, Gornik SG, Beevers N, Atkinson RJA, Miskin D, Neil DM (2012) Hematodinium sp. infection in Norway lobster Nephrops norvegicus and its effects on meat quality. Dis Aquat Org 100:105-112

Bateman KS, Munro J, Uglow B, Small HJ, Stentiford GD (2012) Susceptibility of juvenile European lobster Homarus gammarus fed high- and low-dose white spot syndrome virus (WSSV) infected shrimp products. Dis Aquat Org 100:169-184

> Beevers ND, Kilbride E, Atkinson RJA, Neil DM (2012) Hematodinium infection seasonality in the Firth of Clyde (Scotland) Norway lobster Nephrops norvegicus population: a re-evaluation. Dis Aquat Org 100:95-104

> Behringer DC, Butler MJ IV, Shields JD (2006) Avoidance of disease in social lobsters. Nature 441:421
Behringer DC, Butler MJ IV, Shields JD (2008) Ecological and physiological effects of PaV1 infection on the Caribbean spiny lobster (Panulirus argus Latreille). J Exp Mar Biol Ecol 359:26-33

> Behringer DC, Butler MJ IV, Shields JD, Moss J (2011) Review of Panulirus argus Virus 1-a decade after its discovery. Dis Aquat Org 94:153-160

- Behringer DC, Moss J, Shields JD, Butler MJ IV (2012) PaV1 infection in the Florida spiny lobster fishery and its effects on trap function and disease transmission. Can J Fish Aquat Sci 69:136-144

> Briones-Fourzán P, Baeza-Martínez K, Lozano-Álvarez E (2009) Nutritional indices of juvenile Caribbean spiny lobsters in a Mexican reef lagoon: Are changes over a 10year span related to the emergence of Panulirus argus Virus 1 (PaV1)? J Exp Mar Biol Ecol 370:82-88

Briones-Fourzán P, Candia-Zulbarán RI, Negrete-Soto F, Barradas-Ortiz C, Huchin-Mian JP, Lozano-Álvarez E (2012) Influence of local habitat features on avoidance of disease by Caribbean spiny lobsters in a casita-enhanced bay. Dis Aquat Org 100:135-148

Butler MJ IV, Steneck RS, Herrnkind WF (2006) Juvenile and adult ecology. In Phillips BF (ed) Lobsters: biology and management. Blackwell Scientific Press, Oxford, p 263-309

Butler MJ IV, Behringer DC, Shields JD (2008) Transmission of Panulirus argus virus 1 (PaV1) and its effect on the survival of juvenile Caribbean spiny lobster. Dis Aquat Org 79:173-182

- Candia-Zulbarán RI, Briones-Fourzán P, Lozano-Álvarez E (2012) Variability in clinical prevalence of PaV1 in Caribbean spiny lobsters occupying commercial casitas over a large bay in Mexico. Dis Aquat Org 100:125-133

Castro KM, Angell TE (2000) Prevalence and progression of shell disease in American lobster, Homarus americanus, from Rhode Island waters and the offshore canyons. J Shellfish Res 19:691-700

Castro KM, Cobb JS, Gomez-Chiarri M, Tlusty M (2012) Epizootic shell disease in American lobsters Homarus americanus in southern New England: past, present and future. Dis Aquat Org 100:149-158

- Cawthorn RJ (2011) Diseases of American lobsters: a review. J Invertebr Pathol 106:71-78

Cobb JS, Clancy M, Wahle RA (1999) Habitat based assessment of lobster abundance: a case study of an oil spill. Am Fish Soc Symp 22:285-298

- Cruz-Quintana Y, Rodríguez-Canul R, Vidal-Martínez VM (2011) First evidence of Panulirus argus virus 1 (PaV1) in spiny lobster from Cuba and a clinical estimation of its prevalence. Dis Aquat Org 93:141-147

Ehrhardt NM, Puga R, Butler MJ IV (2010) Large ecosystem dynamics and fishery management concepts: the Caribbean spiny lobster, Panulirus argus, fisheries. In: Fanning L, Mahon R, McConney P (eds) Towards marine ecosystem-based management in the wider Caribbean. Amsterdam University Press, Amsterdam, p 157-175

Food and Agriculture Organization (2012) Global capture production [online query]. www.fao.org/fishery/statistics/global-capture-production/en (accessed July 11, 2012)

> Huchin-Mian JP, Rodríguez-Canul R, Arias-Bañuelos E, Simá-Álvarez R, Briones-Fourzán P, Lozano-Álvarez E (2008) Presence of Panulirus argus Virus 1 (PaV1) in juvenile spiny lobsters Panulirus argus from the Caribbean coast of Mexico. Dis Aquat Org 79:153-156 
Lavallée J, Hammell KL, Spangler ES, Cawthorn RJ (2001) Estimated prevalence of Aerococcus viridans and Anophryoides haemophila in American lobsters Homarus americanus freshly captured in the waters of Prince Edward Island. Canada. Dis Aquat Org 46:231-236

Lavalli KL, Spanier E (2007) Introduction to the biology and fisheries of slipper lobsters. In: Lavalli KL, Spanier E (eds) The biology and fisheries of the slipper lobster. Crustacean Issues, Vol 17. Taylor \& Francis Group-CRC Press, New York, NY, p 3-21

Lightner DV (2011) Virus diseases of farmed shrimp in the Western Hemisphere (the Americas): a review. J Invertebr Pathol 106:110-130

Lozano-Álvarez E, Briones-Fourzán P, Ramírez-Estévez A, Placencia-Sánchez D, Huchin-Mian JP, Rodríguez-Canul R (2008) Prevalence of Panulirus argus Virus 1 (PaV1) and habitation patterns of healthy and diseased Caribbean spiny lobsters in shelter-limited habitats. Dis Aquat Org 80:95-104

Meyers TR, Koeneman TM, Botelho C, Short S (1987) Bitter crab disease: a fatal dinoflagellate infection and marketing problem for Alaskan Tanner crabs Chionoecetes bairdi. Dis Aquat Org 3:195-216

Morado JF (2011) Protistan diseases of commercially important crabs: a review. J Invertebr Pathol 106:27-53

Pascual-Jiménez C, Huchin-Mian JP, Simões N, BrionesFourzán P and others (2012) Physiological and immunological characterization of Caribbean spiny lobsters (Panulirus argus) naturally infected with Panulirus argus Virus 1 (PaV1). Dis Aquat Org 100:113-124

Quinn RA, Metzler A, Smolowitz RM, Tlusty M, Chistoserdov AY (2012) Exposures of Homarus americanus shell to three bacteria isolated from naturally occurring epizootic shell disease lesions. J Shellfish Res 31:485-494

Shields JD (2011) A review of the parasites and diseases of spiny lobsters. J Invertebr Pathol 106:79-91

Shields JD, Behringer DC Jr (2004) A new pathogenic virus in the Caribbean spiny lobster Panulirus argus from the Florida Keys. Dis Aquat Org 59:109-118

Small HJ (2012) Advances in our understanding of the global diversity and distribution of Hematodinium spp. significant pathogens of commercially exploited crustaceans. J Invertebr Pathol 110:234-246
Smolowitz RM, Chistoserdov AY, Hsu A (2005) A description of the pathology of epizootic shell disease in the American lobster, Homarus americanus H. Milne Edwards 1837. J Shellfish Res 24:749-756

Snieszko SF, Taylor CC (1947) A bacterial disease of the lobster (Homarus americanus). Science 105:500

Sosa-Cordero E, Liceaga-Correa MLA, Seijo JC (2008) The Punta Allen lobster fishery: current stratus and recent trends. In: Townsend R, Uchida H (eds) Case studies in fisheries self-governance. FAO Fish Tech Pap No. 504, Rome, p 149-162

Stebbing PD, Pond MJ, Peeler E, Small HJ, Greenwood SJ, Verner-Jeffreys D (2012) Limited prevelance of gaffkaemia (Aerococcus viridans var. homari) isolated from wild caught European lobsters Homarus gammarus in England and Wales. Dis Aquat Org 100:159-167

> Stentiford GD (2012) Histological intersex (ovotestis) in the European lobster (Homarus gammarus) and a commentary on its potential mechanistic basis. Dis Aquat Org 100:185-190

Stentiford GD, Neil DM (2011) Diseases of Nephrops and Metanephrops: a review. J Invertebr Pathol 106:92-109

> Stentiford GD, Bonami JR, Alday-Sanz V (2009) A critical review of susceptibility of crustaceans to Taura syndrome, yellowhead disease and white spot disease and implications of inclusion of these diseases in European legislation. Aquaculture 291:1-17

> Stentiford GD, Neil DM, Peeler E, Shields JD and others (2012) Disease will limit future food supply from the global crustacean fishery and aquaculture sectors. J Invertebr Pathol 110:141-157

Stewart JE, Cornick JW, Spears DI (1966) Incidence of Gaffkya homari in natural lobster (Homarus americanus) populations of the Atlantic region of Canada. J Fish Res Board Can 23:1325-1330

Taylor DM, Khan RA (1995) Observations on the occurrence of Hematodium sp. (Dinoflagellata, Syndinidae), the causative agent of bitter crab disease in Newfoundland snow crab (Chionoecetes opilio). J Invertebr Pathol 65:283-288

Wahle RA, Gibson M, Fogarty M (2009) Distinguishing disease impacts from larval supply effects in a lobster fishery collapse. Mar Ecol Prog Ser 376:185-192 